\title{
EMPOWERMENT OF PRODUCTIVE ZAKAT FUNDS, SOLUTION FOR SMALL BUSINESS: (Evidence From Badan Amil Zakat Nasional Central Borneo) Nor Halipah ${ }^{1}$, Muhammad Riza Hafizi ${ }^{2}$

\author{
riza.hafizi@,iain-palangkaraya.ac.id
}

\begin{abstract}
BAZNAS of Palangka Raya is a zakat management institution that is tasked with collecting, distributing and utilizing zakat. This study aims to analyze the optimization of productive zakat utilization in economic empowerment of mustahik, analysis of the benefits of productive zakat in improving the standard of life of mustahik, and analysis of the constraints that BAZNAS feels in optimizing productive zakat. This research is a qualitative type of research using a descriptive qualitative approach. The research subjects were four productive zakat managers and ten informants from mustahik who received revolving fund loan assistance. This research resulted in conclusions, namely, first, the optimization of zakat utilization in the framework of empowering the mustahik in BAZNAS of Palangka Raya through the Palangka Raya Sejahtera program has not been carried out optimally, due to the absence of supervision, assistance and guidance from BAZNAS so that there mustahik who misuse these funds. Second, the benefits of this program are very helpful in the economic empowerment of mustahik with an increase in business results, a network, an increase in family income, and independence. Third, the obstacles that are often felt by BAZNAS in optimizing them are the lack of human resources in management and in the field, the provision of business capital that is misused by mustahik, the lack of trust of muzaki in institutions, and the large number of ZIS collecting organizations besides BAZNAS.
\end{abstract}

Keywords: Productive Zakat Utilization, Small Trader Capital Solution, BAZNAS

Received: December 19 ${ }^{\text {nd }}, 2020$; Revised: April 28 $8^{\text {th }}, 2021$; Accepted: June 25 ${ }^{\text {nd }}, 2021$

1,2Institut Agama Islam Negeri Palangka Raya and Jl. G. Obos Komplek Islamic Center, Palangka Raya, Kalimantan Tengah

E-mail: ${ }^{2}$ riza.hafizi@iain-palangkaraya.ac.id

DOI: https://doi.org/10.24952/tijaroh.v6i2.2453 


\section{Introduction}

The National Zakat Agency (BAZNAS) of Palangka Raya City as an official governmentowned zakat management institution based on the Presidential Decree of the Republic of Indonesia No.8 of 2001 which functions to manage zakat nationally has an important role in collecting, distributing and utilizing zakat, infaq and alms, as well as can encourage mustahik economic turnover in order to live in a fair and just life. This is a concrete step, to help empower people to find a way out of the cycle of poverty. The National Zakat Agency (BAZNAS) of Palangka Raya City has distributed zakat in productive ways, including by giving zakat in the form of capital loans for community independent businesses in the form of virtue loans. The mustahik who receive productive zakat in the form of loan money are given Rp. 2,000,000 within an eight-month repayment period, the funds returned by the borrower above will be rotated to other mustahik and so on until all needy groups can independently manage and build their economic life. In addition to providing business capital loans to mustahiks, they also encourage these mustahiks to invest so that these funds can add to the next revolving fund and can also add to the mustahik who are entitled to receive.(BAZNAS Palangka Raya City, 21/09/20).

In optimizing the utilization of productive zakat funds, it should not only provide funds but also provide assistance and supervision for the management of these zakat funds, so that they are not misused for personal matters and are not used up to manage businesses without good management. Therefore, it is very necessary to carry out supervision and guidance in maintaining the revolving fund program so that the objectives of the productive zakat program are carried out properly in accordance with the objectives of BAZNAS which provide. In the training and mentoring, religious and social values should also be instilled, so that the recipients of productive zakat funds do not only receive financial assistance but also receive moral and spiritual assistance (Salam \& Risnawati, 2018).

Based on the above, it is interesting to study further about the supervision, assistance, and coaching carried out by BAZNAS in carrying out a productive zakat utilization program, with the formulation of the problems raised, namely how to optimize the utilization of productive zakat BAZNAS Palangka Raya City in economic empowerment of small traders, how to benefit productive zakat BAZNAS Palangka Raya City in improving the standard of life of small traders, and what are the obstacles that BAZNAS feels in optimizing the utilization of productive zakat. In connection with several questions and 


\section{Nor Halipah, Muhammad Riza Hafizi}

Empowerment of Productive Zakat Funds, Solution for Small Business: (Evidence from Badan Amil Zakat Nasional Central Borneo)

background problems, researchers are interested in making scientific research with the title Utilization of Baznas Productive Zakat Funds, In the Form of Loans, Small Trader Capital Solutions (BAZNAS Palangka Raya City).

Management is a special activity related to leadership, direction, personal development, planning, and supervision of work related to the main elements in an activity. The goal is that the results to be achieved can be carried out effectively and efficiently (Astuti \& Zulkifli, 2018). Optimization of an effort to maximize activities so as to realize the desired or desired benefits. Optimization can only be realized if in its realization effectively maximizes or minimizes it is adjusted to certain criteria and objectives. To achieve optimal zakat, in optimizing zakat so that it is managed systematically and structurally which can then be utilized properly, an institution is needed to act as a liaison that can act as a mediator between the beneficiary of zakat and the person who is obliged to pay zakat (Yuniar, 2017). Talking about the zakat utilization system, means discussing interrelated efforts or activities in creating certain goals from the use of the results of zakat in a good, precise and directed manner in accordance with the purpose of zakat that is stipulated (Maguni, 2013). When talking about benefit, it always develops in accordance with the development and guidance of the needs of the people. To determine the level of benefit, usually known as the priority scale. In the management of zakat, there are several principles that must be followed and adhered to so that the management can be effective as expected, namely the principles of openness, voluntaryness, integrity, professionalism and independence (Salam \& Risnawati, 2018).

In an effort to improve the standard of living of the community, the right target empowerment pattern is needed, the right form is to provide opportunities for the poor to plan and implement the development programs they have determined. (Syukron \& Syaifuddin, 2018) By providing training provisions, because training is a very important provision when entering the world of work. The coaching program to become an entrepreneur can go through several stages of activities including:

First, providing Moral Motivation Assistance, these forms of moral motivation are carried out through general or monthly recitation, religious discussions and others (Elfadhli, 2015). Second, business Training Through this training each participant has an understanding of entrepreneurial concepts with all kinds of ins and outs of the problems that exist in them. Third, capital in the form of money is an important factor in the business world, but it is 
not the most important for obtaining financial support, both banking and assistance funds channeled through other business partnerships.

\section{Methods}

This research analyzes the utilization of productive zakat by BAZNAS Palangka Raya in the aspects: productive zakat management, distribution, program supervision, access to mustahik guidance, access to capital and the relationship between mustahik business management. The main subject of research is that the manager of productive zakat consists of four related people, and the researcher enters the informant as reinforcing data in the data provided by the main subject, the informant consists of ten people who get productive zakat itself. While the object of this research is the utilization of BAZNAS productive zakat funds in the form of loan money, small traders' capital solutions (BAZNAS Palangka Raya City). In the research, data collection techniques were used, namely first, observation to observe how the implementation of utilization by BAZNAS, and the efforts of the mustahik who received the assistance. Second, the interview is intended to ask for information directly from the BAZNAS management as the main subject and mustahik become informants as data reinforcement for receiving assistance, interviews conducted through in-depth dialogue, related to productive zakat utilization programs. Third, the documentation of the data to be collected using this technique is the number of mustahik who receive productive zakat assistance, the history of BAZNAS in Palangka Raya City, the business of selling mustahiks, recordings of interviews and photographs of conducting interviews.

\section{Result and Discussion}

Optimizing the utilization of productive zakat BAZNAS Palangka Raya City in the economic empowerment of mustahik

From the interview the researcher conducted with Mr. SP as Deputy Chair III of BAZNAS, Palangka Raya City said: "The allocation of productive zakat in BAZNAS is currently limited to working capital loans, no coaching or training. and guidance to the mustahik who receive it, because of the limitations of our workforce or our human resources and the lack of awareness of the public to pay zakat on BAZNAS Palangka Raya City, and the lack of support from the Government will oblige zakat. From the results of the interview with Mrs. IK as the committee said that: "Most of the data that has been 


\section{Nor Halipah, Muhammad Riza Hafizi}

Empowerment of Productive Zakat Funds, Solution for Small Business: (Evidence from Badan Amil Zakat Nasional Central Borneo)

submitted by the KUA for business capital assistance are Mustahik, then we BAZNAS only select what is needed. And we submit field supervision to the guarantor, we supervise only in terms of repayment, due to the lack of manpower and funds so that we cannot add to existing human resources".

From this there are deficiencies in the supervision of the utilization of productive zakat, namely, where supervision is only left to the guarantor and from the BAZNAS Palangka Raya City does not carry out the supervision, in my opinion it is less effective because later it will cause many undesirable factors, such as misuse. the funds provided. As for the pattern of distribution of productive zakat, namely:

a. Capital

Interview with Mr. UD as the sector of utilization said that: "Capital or the provision of capital is indeed lent to the poor who already have a business but lack the capital to develop their business. And also lent to the poor who want to own a business but do not have capital.

b. Providing Moral Assistance and Motivation

Interview with Mr. SP as deputy chairman III of the National Zakat Agency of Palangka Raya City said: "There is motivation and socialization to inform the importance of tithing and tell that zakat is an obligation of Islam, and there are also those who have rights. Of the zakat, it's like the 8 asnaf, every month we can't hold it, but usually we do it once a year as planned. To provide moral motivation to mustahik who receive revolving fund assistance, we cannot hold it every month, due to funding problems, but every time we receive assistance we always provide guidance and there also provide motivations for them ".

c. Business Training

From an interview with Mr. SP as deputy chairman III said: "The productive zakat program should be accompanied by business training, guidance that provides knowledge to mustahik who are already running a business or starting from scratch. The future business will be better, but Ms. This business training has not been able to be carried out because yes, there are no funds to be given to motivators or business experts, for mustahik it is still not maximum especially for these experts, so yes we still prioritize mustahiq first." As the program progresses, the BAZNAS of Palangka Raya does not supervise, mentor, and mentor mustahik due to the lack of professional human resources and insufficient funds to add new personnel. 


\section{The benefits of productive zakat BAZNAS Palangka Raya City in improving the standard of living of mustahik}

Based on the results of interviews with HS researchers that with the Palangka Raya Sejahtera program, people who were originally in the vortex of loan sharks in terms of borrowing and lending can switch to social funds, namely zakat from the system Islamic economics which of course avoid interest and usury. Furthermore, the mustahik can be independent and run their business. Then the hope is that after receiving assistance, the developed mustahik will later become muzaki. So that there is real social change, initially assisted in the end can help others around him.

As the result of an interview from Ms. SK, who is one of the mustahiks who received capital assistance for a mobile cake business, said: "I am very helped to get help from BAZNAS Palangka Raya City and I feel that life is better than before. Because I started from scratch, I used to have no income every day, now Alhamdulillah, now I can earn every day. And Alhamdulillah, with this assistance, I have been able to give alms even though the nominal is not much every time I add more deposits, because giving alms will get rizky from Allah SWT. " An interview with Mr. AS as a mustahik who received a productive zakat loan said that: "I used assistance from BAZNAS to trade accessories and while trading, I also turned the money around to buy sewing machines to add and develop my business.

An interview with AIS as a mustahik who received a productive zakat loan said that: "The assistance is used to sell cakes around, and also sell them with the help of the children and put them in stalls to sell, with this effort I am grateful to be able to send my child to school, and my husband who meet their daily needs, and Alhamdulillah our life is much better than before I had an income that only expected my husband to work ". Interview with Mrs. IK as the general administration and HR sector said that: "The productive zakat given to mustahik is able to help improve their economy, even though not fully within a year they can immediately try to be independent but they can already try to fulfill their daily life". The same thing said by Mr. UD as the distribution and utilization sector said that: "Productive zakat for economic empowerment can be very empowering, because with the help of capital for their business, previously mustahik could become muzaki". The same thing said by Mr. SS as Deputy Chairman IV BAZNAS Palangka Raya City said that: "productive zakat can empower mustahik and can change a person's life if he seriously develops it and can change mustahik to become an independent muzaki. 


\section{Nor Halipah, Muhammad Riza Hafizi}

Empowerment of Productive Zakat Funds, Solution for Small Business: (Evidence from Badan Amil Zakat Nasional Central Borneo)

According to Mrs. AIS, one of the loan recipients from BAZNAS, Palangka Raya City, stated that the loan she received could increase her business capital. According to him, with this assistance his daily income would increase before the pandemic. This means that the funds provided by BAZNAS Palangka Raya are very helpful in increasing their income. The same thing was felt by Mr. MN, he received capital assistance of Rp. 2000.000, - which is partly used to buy stoves for his angkringan business. According to him, before having a stove his income was only Rp. 150,000, - per day has now increased to around Rp. 200,000, - to Rp. 250,000, - per day. According to him, through the installments applied by BAZNAS Palangka Raya city it has an impact on the motivation and sense of responsibility and discipline of traders to be able to increase their productivity. He also felt that the loan installments were not too burdensome, unlike loans at pawn shops or conventional banks and other loans.

\section{Obstacles felt by BAZNAS Palangka Raya City in optimizing the utilization of productive zakat}

Constraints are obstacles that limit, hinder or prevent the achievement of targets. The obstacles that BAZNAS feel include: Lack of labor in the field or human resources in optimizing the utilization of productive zakat by the Palangka Raya National Zakat Agency to allocate and supervise and foster mustahik in entrepreneurship, due to the limited management of BAZNAS Palangka Raya City. Interview with Mr. SP as the deputy chairman of BAZNAS III Palangka Raya City said that: "It is still not optimal for you to use and manage this productive zakat because of the lack of labor in the field, in terms of allocation, supervision and guidance for the mustahik who receive it. Supervision and guidance should be very necessary to increase the knowledge of the mustahik who receive assistance in the framework of developing their business in the future, we as managers of productive zakat really hope that in the future this program will be more optimal and can touch all the mustahiks in Palangka Raya City.

The zakat funds collected by the National Zakat Agency for Palangka Raya City which are allocated for productive zakat are still very low compared to all the mustahiks in 5 subdistricts of Palangka Raya City. Interview with Mr. SP as deputy chairman III said that: "The zakat funds in BAZNAS Palangka Raya City are currently very minimal, sis, why is it because of the lack of awareness of people paying their zakat officially at BAZNAS and they do not fully trust the institution. this. Zakat payments at BAZNAS can also be via transfer, zakat pick-up service, and come directly to City BAZNAS only. Everything has 
been made easier in terms of collecting, but there are still many people who are not aware of their zakat, be it professional or other zakat.

Lack of awareness of mustahik who do not want to develop their business so that the loans given to mustahik are not in accordance with what BAZNAS expected, and also mustahik still not all of them make these loans for entrepreneurship but for other needs. Interview with Mrs. IK as the general administration and human resource sector of the National Amil Zakat Agency said that: "In the past, we, the KUA, looked for people who were truly incapable and gave these loans to businesses, instead their business didn't last long, because they didn't. can be creative in developing that capital, and they also use it for other needs ". This is due to the absence of more supervision from BAZNAS to always monitor productive zakat recipients, so that they feel they do not want to use these funds other than for business. In connection with the supervision of productive zakat, it should be accompanied by training or coaching for mustahik who receive it so that they know and increase their knowledge both in entrepreneurship and in starting a business and prioritizing their responsibilities.

The number of organizations involved in collecting zakat has made muzaki reluctant to give zakat and prefer to distribute zakat privately. Interview with Mr. SS as the vice chairman of BAZNAS IV Palangka Raya City said: "The number of organizations in collecting zakat today, both those that have obtained permission and those that do not have the permit, make the muzaki not too trusting in the institution, and choose to channel it personally. directly to mustahik ". This greatly affects the target of achieving zakat collection in the BAZNAS institution, and also affects the utilization of mustahik. If a lot of funds are collected, then those who are touched with zakat are also a lot, and vice versa, if the funds collected are small, the mustahik who is assisted is also a little.

\section{Conclusion}

Based on the description in the discussion, the following conclusions can be drawn from this research, first, optimizing the utilization of productive zakat funds from BAZNAS Palangka Raya City for economic empowerment of mustahik is still not optimal, due to the lack of supervision, assistance, guidance by BAZNAS Palangka Raya City so that mustahik misuse funds given and not in accordance with the objectives by BAZNAS itself. The productive utilization program of BAZNAS City Palangka Raya zakat in the form of the Palangka Raya Sejahtera program is very useful and helps in empowering and improving 


\section{Nor Halipah, Muhammad Riza Hafizi}

Empowerment of Productive Zakat Funds, Solution for Small Business: (Evidence from Badan Amil Zakat Nasional Central Borneo)

the standard of living and economy of mustahik. This can be seen from the increase in their income before joining the program and after participating in the productive zakat program. Obstacles faced by BAZNAS in the Palangka Raya Sejahtera program through the business capital assistance program are obstacles for mustahik who are helped through this program, the capital is used for other needs so that business and monthly payments are stuck, lack of BAZNAS human resources in the field in terms of supervision and guidance of mustahik, lack of awareness people to pay zakat and zakat play an important role in improving the welfare of mustahik, and there are many organizations or institutions in collecting zakat so that people are confused about distributing zakat.

\section{References}

Astuti, D., \& Zulkifli, Z. (2018). Manajemen Pengelolaan Zakat di UPZ Instansi Pemerintah Provinsi Riau. Al-Hikmah: Jurnal Agama dan Ilmu Pengetabuan, 15(1), $1-$ 23. https://doi.org/10.25299/jaip.2018.vol15(1).1580

Elfadhli. (2015). ZAKAT PRODUKTIF SEBAGAI SALAH SATU SOLUSI PENGENTASAN KEMISKINAN DAN PENGANGGURAN DI INDONESIA. JURIS JURNAL ILMLAH SYARIAH), 14(1). http://ojs.iainbatusangkar.ac.id/ojs/index.php/Juris/article/view/300

Maguni, W. (2013). PERAN FUNGSI MANAJEMEN DALAM PENDISTRIBUSIAN ZAKAT: DISTRIBUSI ZAKAT DARI MUZAKKI KE MUSTAHIK PADA (BADAN AMIL ZAKAT) BAZ. AL-'ADL, 6(1). https://ejournal.iainkendari.ac.id/index.php/al-adl/article/view/195

Salam, A., \& Risnawati, D. (2018). ANALISIS ZAKAT PRODUKTIF TERHADAP KESEJAHTERAAN MUSTAHIK (STUDI PADA LEMBAGA AMIL ZAKAT INFAQ SHODAQOH NU YOGYAKARTA). JESI JURNAL EKONOMI SYARIAH INDONESLA), $8(2)$. https://ejournal.almaata.ac.id/index.php/JESI/article/view/860 
Syukron, M., \& Syaifuddin, F. (2018). Manajemen Pengumpulan, Pendistribusian Dana Zakat, Infaq, Shodaqah dan Wakaf (Ziswaf) di Lembaga Amil Zakat Nasional (Laznas) Yatim Mandiri. MALLA: Jurnal Ekonomi Islam, 9(2).

Yuniar, K. A. (2017). OPTIMALISASI PENGELOLAAN ZAKAT DAN EFEKTIFITAS AMIL ZAKAT TERHADAP PENINGKATAN PEROLEHAN ZAKAT, INFAK, SEDEKAH (ZIS) DI BADAN AMIL ZAKAT NASIONAL (BAZNAS) TULUNGAGUNG. IAIN Tulungagung. 